\title{
MENINGKATKAN HASIL BELAJAR MATA PELAJARAN KIMIA MELALUI PENILAIAN AUTENTIK PADA SISWA KELAS X-1 SMA NEGERI 1 BARAKA KABUPATEN ENREKANG
}

\section{ARIF CANDIK}

SMAN 1 Baraka, South Sulawesi, Indonesia

\begin{tabular}{ll}
\hline Keyword & Abstrak \\
\hline $\begin{array}{l}\text { Hasil Belajar, } \\
\text { Hasil Belajar }\end{array}$ & $\begin{array}{l}\text { The research was aimed at knowing the learning result improvement of } \\
\text { Kimia, Penilaian } \\
\text { autentik }\end{array}$ \\
$\begin{array}{l}\text { assessment. The subject of research was } 22 \text { students. The data } \\
\text { collection was done by using component of autentic evaluation } \\
\text { involving the students asigment, the student jurnal, sain proses skill, } \\
\text { examination, and the student behavior during the learning process. } \\
\text { The result of research showed that the autentic assessment and the } \\
\text { treatment could improve the chemetry learning result of studens class } \\
\text { X-1 SMAN } 1 \text { Baraka South Sulawesi. }\end{array}$
\end{tabular}

\section{PENDAHULUAN}

Kurikulum adalah seperangkat rencana dan pengaturan mengenai tujuan,isi dan bahan pelajaran serta cara yang digunakan sebagai pedoman penyelenggaraan kegiatan pembelajaran untuk mencapai tujuan pendidikan. Pilotting kurikulum bertujuan untuk meningkatkan kualitas proses pembelajaran serta rancangan pembelajaran yang ada di sekolah. Oleh karena itu kurikulum yang baik akan sangat diharapkan yang berimplikasi kemajuan bangsa dan negara.

Dalam kegiatan belajar mengajar berlangsung proses pengajaran, pembelajaran, penilaian dan evaluasi. Untuk mendapatkan output dari proses belajar mengajar yang berkualitas, keempat proses tersebut harus dilaksanakan dan dikelola dengan baik dan berarti (manageable and
meaningful).Pembelajaran Kimia akan berhasil apabila terjadi strukturisasi situasi untuk membantu siswa mengalami perubahan perilaku. Perubahan dalam diri siswa yang dibawa dari proses pengajaran tersebut merupakan indikasi terselenggaranya proses pembelajaran dengan baik.

Berbicara mengenai evaluasi atau sistem penilaian hasil belajar hingga saat ini tes tertulis berupa tes obyektif atau essay tes masih mendominasi pelaksanaan

evaluasi hasil belajar siswa diseluruh lembaga-lembaga pendidikan termasuk sekolah menengah atas (SMA).

Alat evaluasi berupa tes tertulis, memang menjadi pilihan terbaik yang dapat diandalkan oleh guru. Dengan alasan lebih praktis penggunaannya, baik dalam penyusunan alat evaluasinya, cara penyelenggaraannya maupun koreksinya. 
Namun demikian dari banyak tinjauan, alat evaluasi konvensional ini dipandang banyak memiliki kelemahan, salah satunya adalah hanya mengukur sebagian kecil saja kemampuan siswa. Sebagai contoh seorang siswa merasa terkadang kurang puas terhadap penilaian yang dilakukan oleh guru mereka karena tugas-tugas dan hasil ujiannya tidak puas dikembalikan oleh guru setelah diperiksa. Kalaupun ada sebagian tugas yang pernah dikembalikan oleh guru itupun biasanya tidak dapat mereka jadikan cerminan untuk perkembangan belajar selanjutnya. Akibatnya adalah siswa menjadi malas dan kurang termotivasi untuk belajar, bahkan mempunyai tanggapan kurang baik terhadap guru mereka.

Penerapan teknik evaluasi yang kurang menyeluruh untuk mengukur perkembangan yang dicapai siswa selama proses pembelajaran Kimia akan menyebabkan rendahnya kualitas hasil belajar Kimia. Berkaitan dengan hal inilah maka tugas seorang guru dalam mengevaluasi siswanya, tentu tidak hanya sekedar memberikan tes tertulis lalu berhenti sampai disitu, tetapi hendaknya dapat menilai kinerja siswa secara menyeluruh dan komprehensif. Oleh karena itu, guru harus menggunakan alat untuk mengumpulkan informasi tentang unjuk kerja siswa serta mengadakan penilaian secara kontinu terhadap kemajuan-kemajuan yang dicapai siswa. Untuk tujuan tersebut, salah satu alat yang baik digunakan adalah penilaian autentik.

Berdasarkan pembicaraan awal dengan sesama guru Kimia SMA Negeri 1 Baraka Kabupaten Enrekang, maka diperoleh informasi bahwa masalah sistem evaluasi inilah yang merupakan salah satu hal yang paling penting untuk segera diatasi. Sistem penialaian autentik merupakan sistem penilaian yang ditawarkan dan diharapkan mampu menjadi solusi terhadap sistem penilaian yang digunakan di SMA Negeri 1 Baraka Kabupaten Enrekang melalui penelitian tindakan kelas.
Masalah yang diselidiki dalam penelitian tindakan ini adalah bagaimana meningkatkan hasil belajar Kimia siswa kelas X-1 SMA Negeri 1 Baraka melalui penilaian autentik? Adapun tujuan yang ingin dicapai dalam penelitian ini untuk mengetahui peningkatan hasil belajar Kimia siswa kelas X-1 SMA Negeri 1 Baraka melalui penilaian autentik.

Salah satu komponen dalam pembelajaran dengan pendekatan contextual Teaching and Learning (CTL) adalah penilaian yang sebenarnya (authentic assessment). CTL ini merupakan salah satu pendekatan yang sejalan dengan kurikulum berbasis kompetensi dan Kurikulum Satuan Pendidikan (KTSP) yang diterapkan pada jenjang pendidikan dasar dan menengah sejak tahun 2007. Penerapan pembelajaran yang berbasis kompetensi memerlukan guru yang memahami dan mampu menyajikan satu lingkungan belajar yang dapat membangun dan memperluas pengalaman siswa sebelumnya dan responsif terhadap keragaman tipe pembelajaran siswa.

Gagne (dalam Abdul Haling, 2004:9) mendefinisikan pembelajaran sebagai upaya guru bertujuan untuk mendorong siswa belajar. Pembelajaran merupakan seperangkat peristiwa yang mempengaruhi terjadinya proses belajar siswa. Peristiwa-peristiwa yang mempengaruhi terjadinya belajar siswa, tidak selamanya berada di luar diri siswa tetapi juga berada dalam diri siswa.

$$
\text { Menurut Sumarno,dkk (Fajar, }
$$
2002:89) assesment (penilaian hasil belajar) adalah "proses sistemik untuk menentukan pencapaian hasil belajar peserta didik" sedangkan menurut Blaustein (dalam Ibrahim,2002:5), penilaian dalah proses mengumpulkan informasi dalam membuat keputusan berdasarkan informasi itu. Penilaian biasanya mengacu pada seluruh informasi yang telah diperoleh oleh guru untuk membuat keputusan tentang siswa dan kelasnya. Informasi tentang siswa, dapat 
Jurnal Edumaspul, 1 (1), April 2017 - 25

Arif Candik

diperoleh secara informasi seperti observasi dan perubahan verbal. Penggunaan dalam proses belajar mengajar, penilaian berarti alat ukur untuk mengevaluasi hasil yang telah dicapai dari proses tersebut.

Dengan demikian assessment dapat diartikan sebagai proses pengumpulan data dan informasi yang dilakukan secara sistematis, untuk mengungkapkan kemajuan siswa secara individu untuk menentukan pencapaian hasil belajar dalam rangka pencapaian kurikulum. Sehubungan dengan authentic assessment, Paidi (2000:15) menyatakan bahwa disamping menekankan tindakan penilaian autentik juga menghendaki penilaian secara langsung dan kontinu. Dengan penilaian secara langsung tersebut, diharapkan dapat menghargai kreativitas, inisiatif, pendapat, dan argumen yang dimiliki siswa yang muncul setiap saat.

Nurhadi (2003:53) mengemukakan hal-hal yang bisa digunakan sebagai dasar penilaian prestasi siswa pada penilaian autentik antara lain :(1) proyek/kegiatan dan laporannya,(2) pekerjaan rumah,(3) kuis,(4) karya wisata,(5) presentasi atau penampilan siswa,(6) demonstrasi,(7) laporan, (8) jurnal, (9) hasil tes tertulis, dan (10) karya tulis siswa.Kementerian Pendidikan Nasional (kemendiknas) menyatakan bahwa alat penilaian dalam penilaian autentik berupa pengumpulan kerja siswa (portofolio),hasil karya (produk), penugasan (proyek), kinerja (performance), dan tes tertulis.

Portofolio diartikan sebagai suatu kumpulan pekerjaan siswa dengan maksud tertentu dan terpadu yang diseleksi menurut panduan-panduan tertentu, Menurut Gronlund (Megawati, 2005: 6)

Portofolio mencakup berbagai contoh pekerjaan siswa yang tergantung pada keluasan tujuan. Apa yang harus tersurat, bergantung pada subyek dan tujuan penggunaan portofolio. Contoh pekerjaan siswa memberi dasar pertimbangan kemajuan belajarnya dan dapat dikomunikasikan kepada siswa, orang tua, serta pihak yang berkepentingan.

\section{METODE PENELITIAN}

Penelitin ini merupakan penelitian tindakan kelas (classroom action research) dilaksanakan pada semester ganjil tahun 2015/2016 di Kelas X-1 SMA Negeri 1 Baraka Kabupaten Enrekang dengan jumlah siswa yang menjadi subyek penelitian adalah 32 orang yang terdiri dari 12 siswa laki-laki dan 20 orang siswa perempuan.

\section{Prosedur Penelitian}

\section{a. Tahap perencanaan}

Pada tahap ini peneliti melaksanakan diskusi awal dengan kepala sekolah dan guru mata pelajaran Kimia SMA Negeri 1 Baraka Kabupaten Enrekang untuk membahas permasalahan yang akan dipecahkan dalam penelitian ini.

\section{b. Tahap pelaksanaan}

\section{Siklus I.}

1) Persiapan (a) mengkaji materi pelajaran Kimia siswa kelas X-1 SMA Negeri 1 Baraka kab.Enrekang berdasarkan Implementasi kurikulum 2013, yang meliputi persiapan rencana pembelajaran, pengalokasian waktu dengan menyesuaikan antara waktu yang tersedia dalam kurikulum dengan waktu penelitian, (b) menetapkan dan mempersiapkan jenis-jenis penilaian yang akan dilakukan sesuai dengan materi yang akan diajarkan yaitu bentuk molekul. Adapun jenis penilaian yang akan dilakukan sesuai dengan hasil diskusi antara sesama guru mata pelajaran Kimia, yakni tugas yang dikerjakan siswa di kelas dan dirumah, jurnal, ketrampilan proses, ulangan harian, serta mempersiapkan lembar observasi perilaku dan kreativitas siswa (c) menyusun perangkat pembelajaran berdasarkan format yang berlaku di 
SMA Negeri 1 Baraka Kabupaten Enrekang.

2) Pelaksanaan Tindakan (a) menginformasikan kepada siswa tentang penilaian autentik,(b) melaksanakan proses pembelajaran dan observer melakukan pengamatan dengan menggunakan lembar observasi untuk melihat perilaku dan keaktifan siswa selama proses pembelajaran, (c) mengembangkan aktivitas -aktivitas siswa dalam belajar sesuai dengan lembar pengamatan keaktifan siswa, (d) memberikan tugas-tugas kepada siswa dalam bentuk lembaran kegiatan siswa (LKS),kuis, jurnal, dan mengumpulkan data ketrampilan proses siswa pada saat siswa melakukan praktikum dan pembuatan laporan praktikum dengan menggunakan lembar pengamatan,(e) semua tugas-tugas belajar siswa seperti kuis,pekerjaan rumah, ketrampilan proses sains dan evaluasi diri selama siklus I dikembalikan kepada siswa setelah diperiksa dan diberi nilai kemudian diarsipkan dalam bentuk portofolio,(f) untuk mengetahui sejauh mana hasil belajar yang dicapai siswa pada siklus I, maka pada akhir siklus siswa diberi tes hasil belajar atau ulangan harian.

3) Evaluasi dan refleksi (a) mengevaluasi data yang diperoleh dari hasil belajar siswa pada setiap komponen penilaian autentik, (b) mendiskusikan refleksi yang dibuat bersama pengamat dan membuat rencana tindakan untuk siklus II.

\section{Siklus II}

Kegiatan-kegiatan yang dilakukan pada siklus pertama diulangi pada siklus II setelah memperoleh refleksi baik dari siswa sebagai subyek penelitian maupun peneliti. Pada siklus ini dilakukan tes untuk mengukur peningkatan hasil belajar siswa seperti halnya pada siklus I. Hal yang diperoleh siswa lebih baik dari nilai akhir pada siklus I.

\section{HASIL}

Perubahan yang terjadi dari siklus I ke siklus II merupakan data kualitatif yang dicatat dan diperoleh dari lembar pengamatan pada setiap pertemuan yang dicatat oleh pengamat pada setiap siklus. Frekuensi kehadiran siswa mengalami peningkatan dari siklus I ke siklus II (ratarata kehadiran sebesar $94 \%$ pada siklus I dan $97 \%$ pada siklus II. Hal ini menunjukkan keseriusan siswa untuk mengikuti pelajaran Kimia meskipun jumlah siswa yang hadir tidak selalu seluruhnya (28 sampai 30 siswa) dari 32 siswa. Perhatian siswa pada saat guru membahas materi pelajaran mengalami peningkatan dari siklus I ke siklus II. Hal ini ditandai semakin banyaknya yang melibatkan diri dan aktif memberi tanggapan terhadap pertanyaan guru maupun jawaban dari siswa pada proses belajar-mengajar. Frekuensi siswa yang meminta untuk dijelaskan ulang materi yang kurang dipahami mengalami peningkatan yang ditandai dengan bertambahnya siswa yang masih memerlukan bimbingan dalam menyelesaikan soal-soal latihan ( 4 siswa pada siklus I dan 18 siswa siklus II). Keberanian dan semangat siswa dalam menjawab pertanyaan tentang materi pelajaran Kimia juga mengalami peningkatan, terlihat dari sejumlah siswa yang mengajukan diri atau mengacungkan tangan berulang-ulang untuk memberi jawaban. Keaktifan siswa dalam membantu temannya mengerjakan soalsoal latihan juga mengalami peningkatan, terlihat dari sejumlah siswa yang mengajukan diri untuk membantu temannya menyelesaikan soal di papan tulis.

\section{PEMBAHASAN}

\section{Analisis Deskriptif Hasil Belajar Kimia Siswa pada siklus I}


Skor rata-rata hasil belajar siswa pada siklus I dengan materi pokok bentuk molekul adalah 70,3 dari skor yang dicapai yaitu 100 dengan skor tertinggi yang dicapai adalah 86,5 sedangkan skor terendah adalah 53,80. Setelah dilakukan kategorisasi, terlihat bahwa dari 32 orang siswa yang dijadikan subyek penelitian tidak terdapat siswa yang berada pada kategori sangat rendah, hanya 1 orang $(3,1 \%)$ berada pada kategori rendah, 4 orang $(12,5 \%)$ berada pada kategori sedang, 22 orang $(68,8 \%)$ berada pada kategori tinggi, dan 5 orang $\left(15^{\prime} 6 \%\right)$ berada pada kategori sangat tinggi.

\section{Analisis Deskriptif Hasil belajar Kimia siswa pada siklus II}

Skor rata-rata hasil belajar siswa pada siklus II dengan materi pokok bentuk molekul adalah 76,2 dari skor ideal yang mungkin dicapai yaitu 100 , dengan skor tertinggi 93,3 sedangkan skor terendah 57,5. Dari 32 orang siswa dari setiap komponen penilaian autentik pada siklus II menunjukkan bahwa tidak ada siswa yang berada pada kategori sangat rendah, 2 orang $(6,2 \%)$ yang berada pada kategori sedang, 22 orang $(68,8 \%)$ yang berada pada kategori tinggi, 8 orang $(25 \%)$ yang berada pada kategori sangat tinggi. Hasil analisis deskriptif tersebut menunjukkan bahwa setelah pemberian tindakan selama dua siklus, skor rata-rata hasil belajar siwa mengalami peningkatan. Ini berarti bahwa hasil belajar Kimia siswa kelas X1 SMA Negeri 1 Baraka kabupaten Enrekang dapat ditingkatkan melalui penilaian autentik.

\section{KESIMPULAN}

Berdasarkan hasil yang diperoleh dari setiap siklus tindakan, maka dapat disimpulkan bahwa pemberian penjelasan tentang penilaian autentik, memberi kebebasan kepada siswa untuk memilih topik sendiri dalam membuat jurnal, meningkatkan pemberian soal latihan disertai langkah-langkah penyelesaiannya, memberi bimbingan dalam melakukan unjuk kerja dan lebih mengembangkan aktivitas-aktivitas siswa dapat meningkatkan hasil belajar Kimia pada siswa Kelas X-1 SMA Negeri 1 Baraka Kabupaten Enrekang.

\section{DAFTAR RUJUKAN}

[1] Abd.Haling, 2004, Belajar Pembelajaran, Makassar. Jurusan Kurikulum dan Teknologi Pendidikan FIP UNM

[2] Fajar dan Annie,2002, Portofolio dalam Pembelajaran IPS.Bandung PT Remaja Rosdakarya

[3] Ghofar A, 2003, Pola Induk Pengembangan Sistem Penilaian.Proyek Peningkatan Mutu Sulawesi Selatan. Makassar

[4] Ibrahim, M,2002, Assesmen Autentic Modul,Bio-D- $01 \quad$ Pelatihan Terintegrasi Berbasis Kompetensi Guru mata pelajaran PPKn, Direktorat SLTP, Dirjen Pendidikan Dasar dan Menengah, Departemen Pendidikan Nasional.

[5] Nurhadi, 2003. Peningkatan Kontesktual (Contextual Teaching And Learning) Direktorat Pendidikan Lanjutan Atas.

[6] Paidi, 2000, Implementasi Authentic Assesment dalam Pembelajaran PPKn di Sekolah Lanjutan Atas.Universitas Yogyakarta.

[7] Popham, 1995. Calassroom Assesment How Teacher Need To Know Ass, Ally Bacon. 